\title{
Do oil consumption and economic growth intensify environmental degradation? Evidence from developing economies
}

\author{
Md. Samsul Alam \& Sudharshan Reddy Paramati ${ }^{*, * *}$ \\ Department of Accounting, Finance and Economics \\ Griffith Business School, Griffith University, Australia
}

\begin{abstract}
The purpose of this paper is to empirically investigate the impact of economic growth, oil consumption, financial development, industrialization and trade openness on carbon dioxide $\left(\mathrm{CO}_{2}\right)$ emissions, particularly in relation to major oilconsuming, developing economies. This study utilizes annual data from 1980 to 2012 on a panel of 18 developing countries. Our empirical analysis employs robust panel cointegration tests and a vector error correction model (VECM) framework. The empirical results of three panel cointegration models suggest that there is a significant long-run equilibrium relationship between economic growth, oil consumption, financial development, industrialization, trade openness and $\mathrm{CO}_{2}$ emissions. Similarly, results from VECMs show that economic growth, oil consumption and industrialization have a short-run dynamic bidirectional feedback relationship with $\mathrm{CO}_{2}$ emissions. Long-run (error correction term) bidirectional causalities are found among $\mathrm{CO}_{2}$ emissions, economic growth, oil consumption, financial development, and trade openness. Our results confirm that economic growth and oil consumption have a significant impact on the $\mathrm{CO}_{2}$ emissions in developing economies. Hence, the findings of this study have important policy implications for mitigating $\mathrm{CO}_{2}$ emissions and offering sustainable economic development.
\end{abstract}

Keywords: $\mathrm{CO}_{2}$ emissions; oil consumption; developing economies; panel cointegration techniques

JEL classification: C23; Q43; Q56

* Corresponding author: Email: sudharshanreddy.paramati@griffithuni.edu.au;

** The revised and final version of this paper has been published in 'Applied Economics' Journal. This paper can be cited as: Alam, Md.S. \& Paramati, S.R. (2015) "Do oil consumption and economic growth intensify environmental degradation? Evidence from developing economies” Applied Economics, 47:48, 5186-5203. 


\section{Introduction}

Economic development, energy efficiency and environment protection are some of the most prioritised issues for policymakers and environmental scientists worldwide. Economic growth is highly associated with increased energy use, dominated by fossil fuels combustion and environmental pollution. According to the International Environmental Agency (IEA, 2013), the global primary energy supply, mainly derived from fossil fuels (e.g., oil, coal, natural gas, etc.), more than doubled between 1971 and 2011 due to rapid economic growth and development. At the same time, the growing use of fossil fuels plays a significant role in rising global carbon dioxide $\left(\mathrm{CO}_{2}\right)$ levels. Since the industrial revolution that began in 1870s, the global $\mathrm{CO}_{2}$ emissions from burning fossil fuels have increased from virtually nothing to over 31 gigatons (Gt) in 2011. Hence, a plethora of literature (e.g., Menyah and Wolde-Rufael, 2010; HamitHaggar, 2012; Koch, 2014 etc.) has arisen that analyses the nexus between economic growth, energy consumption and $\mathrm{CO}_{2}$ emissions. However, most of this literature focuses on aggregated data of energy consumption instead of disaggregated components, such as oil, coal and natural gas. Nevertheless, analysis based on disaggregated data of each component is important for formulating and identifying appropriate energy strategies.

Oil, ${ }^{1}$ a dominant energy source, plays an important role in economic growth as a huge amount of oil is used in transport, housing and industries. In 2011, major components of fossil fuels were oil (32\%), coal (29\%) and gas (21\%). The Energy Information Administration (EIA, 2014) indicates that global oil consumption in 2013 was 90.44

\footnotetext{
${ }^{1}$ According to the Energy Information Administration (EIA), the terms "oil" and "petroleum" are sometimes used interchangeably.
} 
$\mathrm{Mb} / \mathrm{d}$ (million barrels per day) and it is expected to increase to $116.8 \mathrm{Mb} / \mathrm{d}$ by 2035 , equivalent to an average yearly growth of $1.3 \%$. Thus, it is expected that the increased use of oil will contribute to the upward trend of $\mathrm{CO}_{2}$ emissions and environmental degradation. British Petroleum (BP, 2007) suggests that oil discharges 0.84 tons of carbon per ton of oil equivalent, while coal and natural gas discharge 1.08 tons and 0.64 tons, respectively. In 2011, oil combustion accounted for 35\% (11.1 $\left.\mathrm{GtCO}_{2}\right)$ of $\mathrm{CO}_{2}$ emissions, while $\mathrm{CO}_{2}$ emissions from coal and natural gas were $44 \%$ (13.7 $\left.\mathrm{GtCO}_{2}\right)$ and $20 \%\left(6.3 \mathrm{GtCO}_{2}\right)$, respectively. Again, it is predicted that emissions from oil will increase to $12.5 \mathrm{GtCO}_{2}$ by 2035, mainly due to increased transport demands (IEA, 2013). Hence, the increased use of oil leads to economic growth on one hand, and causes environmental degradation on the other.

The dual role of oil use raises a range of interesting questions. Does oil consumption help to achieve substantial economic growth? Will the control of oil consumption significantly impede economic progress? Do oil consumption and economic growth intensify $\mathrm{CO}_{2}$ emissions? Should policymakers find any alternative energy resources for sustainable economic development? These questions are major concerns for policymakers and environmental scientists, and require thorough investigations to design and implement efficient energy policies. Thus, this research aims to answer the above questions and provide potential policy implications.

The novelty of our work is fourfold. First, this is the first study to consider the major oil-consuming emerging economies to examine the dynamic relationship between oil consumption, economic growth and $\mathrm{CO}_{2}$ emissions. Second, aside from Al-mulali (2011), previous studies focus only the causal relationship between oil and real GDP 
and ignore $\mathrm{CO}_{2}$ emissions. However, Al-mulali (2011) focuses only on Middle Eastern and North African (MENA) countries, giving emphasis to the major oil producers of the region. Hence, investigating the nexus of oil consumption-growth- $\mathrm{CO}_{2}$ emissions in the major emerging economies will contribute significantly in energy economics literature. Third, most of the literature investigates the causal relationship between oil consumption and economic growth from a bivariate model; an exception is Behmiri and Manso (2012a, 2012b, 2013). The bivariate model is often criticized due to the omitted variables biasness (Stern, 1993). Although Behmiri and Manso (2012a, 2012b, 2013) introduce oil price and exchange rate as transmitting variables, they ignore some other important variables, such as financial development, industrialization and trade, which appear to have a strong influence on economic growth, energy consumption and $\mathrm{CO}_{2}$ emissions (Sadorsky, 2010; Ozturk and Acaravci, 2013 etc.). Further, excluding relevant variable(s) makes not only the estimates spurious and inconsistent but also causality can result from neglected variables (Lütkepohl, 1982). It is possible that the introduction of a third or more variables in the causality framework may not only alter the direction of causality but also the magnitude of the estimates (Loizides and Vamvoukas, 2005). Therefore, investigating the dynamic relationship using a more generalized multivariate model may provide robust and reliable results. This paper attempts to address the gap by examining the dynamic relationship between oil consumption, economic growth and $\mathrm{CO}_{2}$ emissions in 18 emerging countries for the period 1980 to 2012 by including financial development, industrialization and trade openness as control variables. The countries considered in this study are Algeria, Argentina, Brazil, China, Colombia, Egypt, India, Indonesia, Iran, Malaysia, Mexico, 
Nigeria, Pakistan, the Philippines, South Africa, Thailand, Turkey and Venezuela. Finally, our modelling approach is novel in energy economics literature as we use a panel approach for the analysis. We apply three panel cointegration techniques to explore the long-run equilibrium relationship between the variables, and the short-run and long-run causalities are investigated using a vector error correction model (VECM) framework.

The paper is divided into six sections. Section II presents a critical review of the literature, including methods and findings. Section III introduces the empirical methodologies that are adopted in this paper. Section IV presents the nature of data and preliminary statistics. Section V reports the empirical results of the study. Finally, section VI presents the conclusions and policy implications arising from this study.

\section{Literature Review}

The nexus between energy consumption and economic growth has been extensively investigated over the last few decades. Even so, there seems to be no consensus on the direction of the causality. The four hypotheses of conservation, growth, feedback and neutrality have been developed with a large amount of literature available to support each of these. The conservation hypothesis argues that a unidirectional causality runs from GDP to energy use and therefore undertaking an energy conservation policy would not result negatively on economic growth (Zhang and Cheng, 2009; Aklino, 2010). Conversely, the growth hypothesis advocates that energy consumption influences GDP growth and the reduction of energy use will hamper economic growth (Stern, 1993; Yaun et al., 2007). The feedback hypothesis suggests that GDP and energy consumption 
Granger causes each other (Wolde-Rufael and Menyah, 2010; Tsani, 2010), while the neutrality hypothesis proposes that there is no causality between these two variables and, therefore, environment-friendly policies are appreciated (Alam et al., 2011).

The empirical evidence between economic growth, energy consumption and $\mathrm{CO}_{2}$ emissions is also inconclusive. A group of studies (Halicioglu, 2009; Kim et al., 2010 etc.) have revealed that there is a positive significant relationship between economic growth, energy consumption and $\mathrm{CO}_{2}$ emissions, while Apergis et al. (2010) and Gosh (2010) have found a negative relationship between energy consumption and $\mathrm{CO}_{2}$ emissions. Another strand of literature has found a bidirectional causality between energy consumption and $\mathrm{CO}_{2}$ emissions (Pao and Tsai, 2010; Lean and Smyth, 2010) and, economic growth and $\mathrm{CO}_{2}$ emissions (Pao and Tsai, 2010). However, Menyah and Wolde-Rufael (2010) conclude no Granger causality between renewable energy and $\mathrm{CO}_{2}$ emissions, and Soytas and Sari (2009) reveal income has no effect on $\mathrm{CO}_{2}$ emissions. Similar to the energy-growth- $\mathrm{CO}_{2}$ relationship, the causality between oil consumption and economic growth is also conflicting.

The empirical studies of the causality tests between oil consumption and economic growth are summarized in Table 1 . The assessment of the existing literature review regarding oil consumption-growth suggests that four kinds of causality exist. First, the unidirectional causality from oil consumption to economic growth suggests that increases in oil consumption have a positive effect on economic growth, and a shortage of oil supply may have an adverse effect on economic growth through production and transportation. Lee and Chang's (2005) pioneering study discover unidirectional causality from oil use to economic growth. Considering Taiwan as a case study, the 
authors examine the relationship between energy (oil, gas, electricity and coal) consumption and economic growth between 1954 and 2003. Employing Johansen’s cointegration test, the study provides empirical evidence that oil consumption leads to economic growth. The same finding is also revealed in China. He et al. (2005) argue that both oil consumption and $\mathrm{CO}_{2}$ emissions in China increased significantly due to the increased demand of oil in the Chinese road transport sector, and predict that both oil consumption and $\mathrm{CO}_{2}$ emissions will rapidly increase in this sector in the next 25 years. Furthermore, Halkos and Tzermes (2011) claim that oil consumption helps to increase economic efficiency in 42 economies across the world.

Second, the unidirectional causality running from economic growth to oil consumption implies that economic growth increases oil consumption. The rationality to support this view is that people are expected to consume more oil as their income increases. Moreover, the use of oil in transportation and production also increases along with economic growth. These arguments are supported by a number of studies, such as Yang (2000) and Aqeel and Butt (2001). Yang (2000) investigates the link between oil consumption and real GDP per capita in Taiwan from 1954 to 1997. The Engle-Granger causality test yields evidence of unidirectional causality from GDP per capita to oil consumption. Aqeel and Butt (2001) also report the similar finding in the case of Pakistan. Their study uses Hsiao’s Granger causality test and finds that economic growth leads to increase petroleum consumption.

Third, Yaun et al. (2008), Al-mulali (2011), Behmiri and Manso (2012a; 2012b; 2013) and, Park and Yoo (2014) find a bidirectional causal relationship between oil use and economic growth. That is, oil consumption and economic growth Granger cause each 
other and affect simultaneously. In their study, Zou and Chau (2006) investigate the short- and long-run impacts between oil use and economic growth in China. Using time series data from 1953 to 2002, the study concludes that oil consumption has a significant impact on China's economic growth. In another study on China, Yaun et al. (2007) explore the causality between energy consumption and economic growth at both aggregated and disaggregated levels. Employing a neo-classical aggregate production model, their empirical findings suggest that a bidirectional relationship exists between oil use and GDP. Zamani (2007) also examines the link between different kinds of energy and overall GDP, controlling industrial and agricultural output in a case study of Iran. Using an error correction model (ECM) framework, the study discovers that petroleum consumption and GDP growth affect each other in the long-run. Al-mulali (2011) examines the effect of oil consumption on the economic growth and $\mathrm{CO}_{2}$ emissions of MENA countries. From a panel data set for the period 1980-2009, the study finds that bidirectional causality exists between oil consumption, economic growth and $\mathrm{CO}_{2}$ emissions.

Another study by Behmiri and Manso (2012a) employ a trivariate framework to explore the nexus between oil consumption, economic growth and oil prices in Portugal from 1980 to 2009. The study uses both panel cointegration and Granger causality tests and reports that there is bidirectional causality between oil consumption and economic growth. The same authors (Behmiri and Manso, 2012b) investigate the same issue in 27 Organization for Economic Cooperation and Development (OECD) countries, and provide empirical evidence of bidirectional relationship existence both in the short- and long-run. In a further study, the authors (Behmiri and Manso, 2013) examine the same 
issue in the major economies of Sub-Saharan Africa during 1985-2011, where they divide the selected countries into the two major groups of net oil- importing and exporting countries. The Granger causality test suggests that, in the short-run, there is bidirectional causality and unidirectional causality from oil use to GDP growth in oilimporting and exporting countries, respectively. However, there is bidirectional causality between the variables in both regions in the long-run. More recently, Park and Yoo (2014) examine the causal relationship between oil consumption and economic growth in Malaysia where oil use and real GDP has rapidly increased over the last couple of decades. From ECM models, the study confirms that bidirectional causality exists between oil consumption and economic growth. Moreover, Bildirici and Kaykci (2004) also support the existence of bidirectional causality between oil production and GDP growth in Eurasian countries.

Finally, a few studies report the absence of a causal relationship, which implies that there is no causality between economic growth and oil consumption. To be specific, Wolde-Rufael (2004) explores the causal relationship between disaggregate industrial energy consumption and economic growth in the Chinese province of Shanghai. Using time series data for the period of 1952 to 1999, the study argues that oil consumption does Granger cause economic growth and vice versa. Fatai et al. (2004) also make the same finding in the context of New Zealand. The authors investigate the impact of various kinds of energy consumption and economic growth in six different countries, including Australia, New Zealand, India, Indonesia, Thailand, and the Philippines, covering the period between 1960 and 1999. From Johansen's cointegration and Toda- 
Yamamoto causality tests, the study discovers that no Granger causality running in any direction between oil use and GDP growth in New Zealand.

A number of studies document in the literature that financial development, industrialization and trade openness can also have a significant impact on energy consumption and $\mathrm{CO}_{2}$ emissions. First, financial development is the indication of an efficient stock market and financial intermediation, which gives a platform for listed companies to lower their cost of capital with increasing financial channels, disseminating operating risks and optimizing asset/liability structure. This eventually encourages new installations and investments in new projects that then have a considerable impact on energy consumption and $\mathrm{CO}_{2}$ emissions. Moreover, the presence of an efficient financial system leads to more consumer-loan activities, which indeed makes consumers to buy more energy-consuming products and causes for more $\mathrm{CO}_{2}$ emissions. These arguments are empirically supported by Jensen (1996) and Zhang (2011). Jensen (2011) argues that financial development encourages $\mathrm{CO}_{2}$ emissions as it increases manufacturing production. Employing VECM and variance decomposition approach, Zhang (2011) finds that financial development significantly increases $\mathrm{CO}_{2}$ emissions and thereby environmental degradation in China.

However, a number of studies reveal a positive relationship between financial development and environmental quality. For instance, Lanoie et al. (1998) argue that an efficient financial market provides incentives to its companies/firms to comply with environmental regulations that help to mitigate environmental degradation. Kumbaroglu et al. (2008) also support Lanoie et al. (1998) findings by concluding that financial development helps to significantly reduce $\mathrm{CO}_{2}$ emissions in Turkey by using advanced 
greener technology in the energy sector. Tamazian et al. (2009) investigate the effect of economic and financial development on $\mathrm{CO}_{2}$ emissions in some of the most emerging economies, including Brazil, Russia, India and China (BRIC) nations. Using panel data over the period 1992-2004, the authors find that both factors are essential for $\mathrm{CO}_{2}$ reductions. Tamazian and Rao (2010) also inspect the impact of financial, institutional and economic development on $\mathrm{CO}_{2}$ emissions for 24 transitional economies during 1993 to 2004. Using a GMM model, the study reports that financial development helps lower $\mathrm{CO}_{2}$ emissions by promoting investment in energy efficient sector. However, the authors point out that financial liberalization may be harmful for environmental quality if it is not accomplished within a strong institutional framework. Following the ARDL bound testing procedure; Jalil and Feridun (2011) also present the similar findings using Chinese aggregate data over the period 1953-2006.

Second, the link between industrialization, energy consumption and $\mathrm{CO}_{2}$ emissions has become a growing interest among the energy economists and policymakers around the world. For example, Jones (1991) examines industrialization and energy use. Using data from developing countries, the study reveals that industrialization increases the consumption of energy. York et al. (2003) examine the impact of industrialization and urbanization on the environment and find that both of these factors degrade environment quality through increasing $\mathrm{CO}_{2}$ emissions. Employing a wide range of data from 99 countries during the 1975-2005 period, Poumanyyoung and Kaneko (2010) find that a $1 \%$ increase in industrial output increases $0.069 \%$ of energy consumption, a significant finding for low- and middle-income countries. Using heterogeneous panel regression, Sadorsky (2013) claims that industrialization increases energy intensity both in the 
short- and long-run for a panel of 76 developing countries. The same author (Sadorsky, 2014) makes the same finding in the context of emerging economies. Considering Bangladesh as a case study, Shabaz et al. (2014) examine the relationship between industrialization, electricity consumption and $\mathrm{CO}_{2}$ emissions. The ARDL bounds testing approach suggests that the Enviornmental Kuznets curve (EKC) exists between industrial output and environment. All of these studies argue that industrialization requires more equipment and machineries to carry out the production of goods and services, which will then consume more energy and releases higher $\mathrm{CO}_{2}$ emissions than the traditional agricultural or manufacturing activities.

Finally, trade openness also has a considerable impact on energy consumption. An increase in exports and imports of goods and services requires more economic activities, such as production, processing and transportation. These activities will intensify energy consumption and $\mathrm{CO}_{2}$ emissions. There is an extensive amount of literature, such as Jena and Grote (2008), Ghani (2012) and Sadorsky (2011, 2012), who claims that trade openness increases energy consumption. However, only a few studies examine the link between trade openness and $\mathrm{CO}_{2}$ emissions, with the pioneering study by Grossman and Krueger (1991). Subsequently, similar research questions have also been examined by a number of studies, such as Lucas et al. (1992), Wyckoff and Roop (1994), Nahman and Antrobus (2005), etc. However, all of these earlier studies fail to find conclusive evidence of the relationships between trade and environmental quality. Halicioglu's study (2009), which uses Turkish data, is probably the first to reveal that trade is one important determinant of $\mathrm{CO}_{2}$ emissions. Hossain (2011) also finds a positive relationship between trade openness and $\mathrm{CO}_{2}$ emissions in newly industrialized 
countries. Moreover, Ozturk and Acaravci (2013) also found that foreign trade increases $\mathrm{CO}_{2}$ emissions in Turkey for the 1960-2007. A recent study by Ren et al. (2014) examines the impact of international trade on $\mathrm{CO}_{2}$ emissions in China for the period 2000-2010. Based on the two-step GMM estimation, the study argues that China's trade surplus is one of the important reasons for the rapidly increasing $\mathrm{CO}_{2}$ emissions.

\section{[Insert Table 1 Here]}

The above review suggests that the relationship between oil consumption and economic growth varies across countries, periods and methods. Moreover, most of the studies have been conducted on individual Asian countries using time series techniques, and panel frameworks are scarce. As most of the studies address the causality within an individual country, their findings cannot be generalised as the results suffer from a short data span that leads to a reduction of the unit root and cointegration test power. Further, most of the existing literature focuses on a causal link from a bivariate model and ignores the dynamic relationship from a multivariate model. Hence, this study is a modest attempt to address these limitations, and to contribute to the body of knowledge in this area and provide potential policy implications for sustainable economic growth.

\section{Methodology}

In this paper, we use panel econometric models for the analysis because of the numerous advantages it offers in comparison to cross-section and time series models. For example, a panel data set not only provides more information on the given variables but also control for individual heterogeneity that exists across cross-sections. This ultimately increases the efficiency and reliability of the econometric estimation. 
Additionally, panel data set estimation can assist in overcoming the problems connected with insufficient distributions and non-stationarity issues that are often experienced in time series data sets, particularly in the case of shorter duration. The panel econometric models are based on the following variables: $\mathrm{CO}_{2}$ emissions $\left(\mathrm{CO}_{2} \mathrm{E}\right)$, which is a function of financial development (FD), economic growth (GDPPC), industrialization (IND), oil consumption (OILCON) and trade openness (TRDOPN). The basic and general framework for determinants of $\mathrm{CO}_{2}$ emissions can be written as follows:

$$
C O_{2} E_{i t}=f\left(F D_{i t}, G D P P C_{i t}, I N D_{i t}, O_{L C O N}, T R D O P N_{i t}, Z_{i}\right)
$$

Eq. (1) can be parameterized as follows:

$$
C O_{2} E_{i t}=F D_{i t}^{\beta_{1 i}} G D P P C_{i t}^{\beta_{2 i}} I N D_{i t}^{\beta_{3 i}} \operatorname{OILCON}_{i t}^{\beta_{4 i}} \operatorname{TRDOPN}_{i t}^{\beta_{5 i}} V_{i}
$$

Eq. (2) can be re-written in a simple regression framework by adding a random error term as follows:

$\ln \left(C O_{2} E_{i t}\right)=\beta_{1 i} \ln \left(F D_{i t}\right)+\beta_{2 i} \ln (G D P P C)_{i t}+\beta_{3 i} \ln \left(I N D_{i t}\right)+\beta_{4 i} \ln \left(O I L C O N_{i t}\right)+\beta_{i 5} \ln \left(T R D O P N_{i t}\right)+Z_{i}+\varepsilon_{i t}$

In Eq. (3), In represents the natural logarithms, countries are denoted by the subscript $i$ $(i=1, \ldots \ldots, N)$, and $t$ denotes the time period $(t=1, \ldots \ldots ., T)$. This equation is a fairly general specification, which accounts for individual country fixed effects $(Z)$ and a stochastic error term $(\varepsilon)$.

Panel unit root tests

In this study, we start with panel unit root tests. Applying unit root tests on a time series data set has become an important factor for researchers to understand the distributional 
properties of a data series and also the order of integration of the variables before applying any econometric model. At the same time, applying unit root tests on a panel data series is a new phenomenon. Thus, the growing popularity of panel data set among economists has attracted a great deal of attention towards the application of panel unit root tests. Further, the results from panel unit root test are more consistent than those of normal unit root test for an individual time series. Given these advantages, in this study, we use two panel unit root tests that investigate the common as well as individual unit root processes on each of the variables. For the former, we employ Breitung (2000) tstat test, while the latter is examined using Im et al. (2003) test.

\section{Panel cointegration tests}

We apply panel cointegration techniques to explore the long-run equilibrium relationship between $\mathrm{CO}_{2}$ emissions, economic growth, financial development, industrialization, oil consumption and trade openness in a sample of 18 emerging economies. Panel cointegration techniques provide better results than models estimated from the individual time series. This is due to the fact that the models estimated from cross-sections of a time series data set have a greater degree of freedom and provide consistent results. Therefore, we employ three panel cointegration models: a Fisher-type cointegration test (Maddala and $\mathrm{Wu}, 1999)$; the Kao (1999) cointegration test; and the Pedroni (1999, 2004) cointegration test. The Fisher test is based on the Johansen combined test while the second (Kao) and third (Pedroni) cointegration tests are based 
on the Engle and Granger (1987) two-step (residual-based) cointegration approach. The following section provides a brief description on the above panel cointegration models. ${ }^{2}$

Fisher-Johansen panel cointegration test. As mentioned above, we aim to explore the long-run relationship between the given variables. Thus, we start with Fisher-Johansen panel cointegration test. Fisher (1932) developed a combined test that utilizes the results of individual independent tests. More recently, Maddala and Wu (1999) apply Fisher’s test to propose an alternative method for testing a cointegration relationship in a panel data set by combining tests from individual cross-sections to acquire a test statistic for the entire panel. The suitable lag length for this test is selected based on the Schwarz information criterion (SIC). The null hypothesis of no cointegration is tested against the alternative hypothesis of cointegration. This test can be described with the following model: if $\pi_{i}$ is the p-value from an individual cointegration test for a cross-section $i$, the panel under the null hypothesis is:

$-2 \sum_{i=1}^{N} \log \left(\pi_{i}\right) \rightarrow x_{2 N}^{2}$

where the $x^{2}$ value is based on the MacKinnon et al. (1999) p-values for Johansen’s trace and maximum eigenvalue tests.

Kao cointegration (Engle-Granger based) test. The Kao panel cointegration test is based on Engle and Granger (1987) two-step procedure. This cointegration test clearly defines intercepts for cross-sections and homogenous coefficients on the first-stage regressors. The Kao (1999) has described the bivariate regression model as follows:

\footnotetext{
${ }^{2}$ Due to space limitation, detailed equations and a detailed discussion of the panel cointegration models are excluded.
} 
$y_{i t}=\alpha_{i}+\beta x_{i t}+\varepsilon_{i t}$

$y_{i t}=y_{i t-1}+v_{i, t}$

$x_{i t}=x_{i t-1}+e_{i, t}$

where $y$ and $x$ are assumed to be integrated of order one, i.e., I (1), and $i$ and $t$ denote country and time period, respectively. The first-stage regression can be carried out using Eq. (5) where $\alpha_{i}$ is heterogeneous, $\beta_{i}$ is homogenous across cross-sections, and $\varepsilon_{i t}$ is the residual term. This cointegration test utilizes an augmented version of the DickeyFuller test for testing the null hypothesis of no cointegration against the alternative hypothesis of cointegration. The appropriate lag length for this test is chosen based on the SIC.

Pedroni cointegration (Engle-Granger based) test. The Pedroni (1999, 2004) panel cointegration test is also based on Engle and Granger (1987) two-step procedure. The Pedroni test provides seven statistics for tests of the null hypothesis of no cointegration in heterogeneous panels. These seven statistics can be classified into two parts: the first four statistics represent within-dimension (panel tests) and the last three statistics constitute between-dimension (group tests). These seven tests are performed based on the residuals from Eq. (3). The null hypothesis of no cointegration ( $\rho_{i}=1$ for all $i$ ) is tested against the alternative hypothesis of $\rho_{i}=\rho<1$ for all $i$ for the within-dimension. Likewise, in the case of the group-means approach, it is less restrictive because it does not need a common value of $\rho$ under the alternative. Therefore, for the group-means approach, the alternative hypothesis is $\rho_{i}<i$ for all $i$. As we discussed above, the between-dimension tests are less restrictive; therefore, they allow for heterogeneous 
parameters across the cross-sections. The lag length for this test is selected based on the SIC.

\section{Panel Granger causality test}

In this section, we describe the methodology that aims to explore the dynamic causal relationship between $\mathrm{CO}_{2}$ emissions, economic growth, financial development, industrialization, oil consumption and trade openness. Engle and Granger (1987) argue that if non-stationary variables are cointegrated in the long-run, then the vector error correction model (VECM) can be applied for exploring the direction of causality among the variables in the short-run as well as in the long-run. The short-run Granger causality can be established by conducting a joint test of the coefficients based on the F-test and the $x^{2}$ test. Likewise, the long-run Granger causality between the variables can be understood through the statistical significance of the lagged error term in the VECM framework based on the t-statistics.

The panel Ganger causality test for short-run and long-run can be described based on the following equations:

$$
\begin{aligned}
& \Delta C O_{2} E_{i t}=\alpha_{i t}+\beta_{i t} e c t_{i t-1}+\sum_{i=1}^{K} \vartheta_{i t} \Delta C O_{2} E_{i t-1}+\sum_{i=1}^{K} \delta_{i t} \Delta F D_{i t-1}+\sum_{i=1}^{K} \phi_{i t} \Delta G D P P C_{i t-1}+\sum_{i=1}^{K} \varphi_{i t} \Delta I N D_{i t-1}+\sum_{i=1}^{K} \gamma_{i t} \Delta O I L C O N_{i t-1}+\sum_{i=1}^{K} \theta_{i t} T R D O P N_{i t-1}+\mu_{i t} \\
& \Delta F D_{i t}=\alpha_{i t}+\beta_{i t} e c t_{i t-1}+\sum_{i=1}^{K} \vartheta_{i t} \Delta F D_{i t-1}+\sum_{i=1}^{K} \delta_{i t} \Delta C O_{2} E_{i t-1}+\sum_{i=1}^{K} \phi_{i t} \Delta G D P P C_{i t-1}+\sum_{i=1}^{K} \varphi_{i t} \Delta I N D_{i t-1}+\sum_{i=1}^{K} \gamma_{i t} \Delta O I L C O N_{i t-1}+\sum_{i=1}^{K} \theta_{i t} T R D O P N_{i t-1}+\mu_{i t} \\
& \Delta G D P P C_{i t}=\alpha_{i t}+\beta_{i t} e c t_{i t-1}+\sum_{i=1}^{K} \vartheta_{i t} \Delta G D P P C_{i t-1}+\sum_{i=1}^{K} \delta_{i t} \Delta C O_{2} E_{i t-1}+\sum_{i=1}^{K} \phi_{i t} \Delta F D_{i t-1}+\sum_{i=1}^{K} \varphi_{i t} \Delta I N D_{i t-1}+\sum_{i=1}^{K} \gamma_{i t} \Delta O I L C O N_{i t-1}+\sum_{i=1}^{K} \theta_{i t} T R D O P N_{i t-1}+\mu_{i t} \\
& \Delta I N D_{i t}=\alpha_{i t}+\beta_{i t} e c t_{i t-1}+\sum_{i=1}^{K} \vartheta_{i t} \Delta I N D_{i t-1}+\sum_{i=1}^{K} \delta_{i t} \Delta C O_{2} E_{i t-1}+\sum_{i=1}^{K} \phi_{i t} \Delta F D_{i t-1}+\sum_{i=1}^{K} \varphi_{i t} G D P P C_{i t-1}+\sum_{i=1}^{K} \gamma_{i t} \Delta O I L C O N_{i t-1}+\sum_{i=1}^{K} \theta_{i t} T R D O P N_{i t-1}+\mu_{i t}
\end{aligned}
$$


$\Delta O I L C O N_{i t}=\alpha_{i t}+\beta_{i t} e c_{i t-1}+\sum_{i=1}^{K} \vartheta_{i t} \Delta O I L C O N_{i t-1}+\sum_{i=1}^{K} \delta_{i t} \Delta C O_{2} E_{i t-1}+\sum_{i=1}^{K} \phi_{i t} \Delta F D_{i t-1}+\sum_{i=1}^{K} \varphi_{i t} \Delta G D P P C_{i t-1}+\sum_{i=1}^{K} \gamma_{i t} \Delta I N D_{i t-1}+\sum_{i=1}^{K} \theta_{i t} \operatorname{TRDOPN}_{i-1}+\mu_{i t}$

$\Delta T R D O P N_{i t}=\alpha_{i t}+\beta_{i t} e c t_{i-1}+\sum_{i=1}^{K} \vartheta_{i t} \Delta T R D O P N_{i t-1}+\sum_{i=1}^{K} \delta_{i t} \Delta C O_{2} E_{i t-1}+\sum_{i=1}^{K} \phi_{i t} \Delta D_{i t-1}+\sum_{i=1}^{K} \varphi_{i} \Delta G D P P C_{i t-1}+\sum_{i=1}^{K} \gamma_{i t} \Delta I N D_{i t-1}+\sum_{i=1}^{K} \theta_{i t} O I L C O N_{i t-1}+\mu_{i t}$

where $\Delta$ is the first difference operator, $\alpha_{i t}$ is the constant term, $\beta_{i t}, \vartheta_{i t}, \delta_{i t}, \phi_{i t}, \varphi_{i t}, \gamma_{i t}$ and $\theta_{i t}$ are the parameters, $e c t_{i t-1}$ is the error correction term obtained from the VECM models, $k$ is the lag length and $\mu_{i t}$ is the white-noise error term.

\section{Data and Preliminary Statistics}

Nature of data and measurement

The study uses a balanced panel data set of 18 emerging economies across the world from 1980 to 2012. The considered countries in the sample are as follows: Algeria (ALG), Argentina (ARG), Brazil (BRA), China (CHI), Colombia (COL), Egypt (EGY), India (IND), Indonesia (INDO), Iran (IRA), Malaysia (MAL), Mexico (MEX), Nigeria (NIG), Pakistan (PAK), the Philippines (PHI), South Africa (SOU), Thailand (THA), Turkey (TUR) and Venezuela (VEN). The countries are selected according to the following two criteria; first, the country should consume at least 200,000 barrels of petroleum per day on average from 1980 to 2012; second, the country should have a developing economy. ${ }^{3}$ Annual data on $\mathrm{CO}_{2}$ emissions, economic growth, financial development, industrialization, oil consumption and trade openness is employed.

\footnotetext{
${ }^{3}$ All developed countries (as defined by the World Bank) are excluded from the analysis, because developing countries often contribute higher $\mathrm{CO}_{2}$ emissions, which eventually degrade the environment. Hence, we aim to understand the major contributors of $\mathrm{CO}_{2}$ emissions in developing countries and provide potential policy implications for mitigating $\mathrm{CO}_{2}$ emissions and sustainable economic growth.
} 
The measurement of the variables are as follows: $\mathrm{CO}_{2}$ emissions are measured per capita metric tons $\left(\mathrm{CO}_{2} \mathrm{E}\right)$; economic growth is captured by real GDP per capita (GDPPC, constant 2005 US\$); financial development (FD) is measured by domestic credit to private sector as a share of GDP; industrialization (IND) is measured using total value added by the industry as a share of GDP; per capita petroleum consumption (litres) is used as a proxy for oil consumption; and trade openness (TRDOPN) is measured by the sum of exports and imports (goods and services) as a share of GDP. Data on petroleum consumption is collected from EIA while data on $\mathrm{CO}_{2} \mathrm{E}$, FD, GDPPC, IND and TRDOPN are collected from the World Development Indicators' (WDI) online data source (World Bank). We transformed all the variables into natural logarithms before estimating any economic models, since log-linear specification can produce better results than the linear functional form of the model.

Time-series trend of $\mathrm{CO}_{2}$ emissions, oil consumption and per capita GDP

Fig. 1 shows time series plots of per capita $\mathrm{CO}_{2}$ emissions (metric tons) for each of the countries. Overall, $\mathrm{CO}_{2}$ emissions increased over time for all countries except Nigeria. On average, South Africa, Venezuela, Iran and Malaysia have the highest per capita $\mathrm{CO}_{2}$ emissions, while Nigeria, Pakistan and the Philippines have the lowest. The graphs also reveal that Algeria, Argentina, Colombia, Mexico, Nigeria, the Philippines, South Africa and Venezuela observed a sharp volatile growth in $\mathrm{CO}_{2}$ emissions over the last three decades, while China, India, Pakistan, Thailand and Turkey experienced steady growth.

\section{[Insert Fig.1 Here]}


Fig. 2 exhibits time series graphs of per capita oil consumption (liters) for each of the selected emerging economies. These graphs suggest that oil consumption experienced an upward trend for all of the countries, except Colombia, Mexico, Nigeria and the Philippines. However, the strength of the trend differs significantly from one country to another. These graphs indicate that, on average, Venezuela, Iran and Mexico have the highest per capita oil consumption, while India, Pakistan, Nigeria, China and the Philippines have the lowest. Over the last three decades, the per capita oil consumption in China, India and Indonesia is steadily increasing.

\section{[Insert Fig.2 Here]}

Fig. 3 presents the time series plots of real GDP per capita (constant 2005, US\$) for each of the selected countries. The graphs show that all of the countries enjoyed positive GDP (per capita) growth over the time period. The graph indicates that Mexico, Turkey, Venezuela and South Africa have the highest per capita GDP, while India, Pakistan and Nigeria have the lowest. Moreover, the GDP per capita growth in China, Egypt, India, Indonesia, Malaysia, Pakistan, and Turkey was impressive as these countries enjoyed steady growth across time. Further, the figures indicate that, during 2007 to 2009, China and India were affected the least by the global financial crisis, while Mexico, Turkey and Venezuela were affected the most.

\section{[Insert Fig.3 Here]}




\section{Average annual growth rates}

Table 2 displays the average annual growth rates for all the countries during the period 1980 to 2012 as percentages. ${ }^{4}$ All of the selected countries experienced increased $\mathrm{CO}_{2}$ emissions, except for Nigeria (-0.15\%). Thailand (5.54\%), China (4.6\%) and Malaysia (4.6\%) had the highest growth rates of $\mathrm{CO}_{2}$ emissions, while Colombia and Mexico had the lowest growth rate. The highest financial development growth was recorded in Indonesia (6.05\%), Brazil (6.01\%) and Turkey (5.37\%), while Iran (-1.71\%), Pakistan ($0.69 \%)$ and Venezuela (-0.21\%) experienced negative growth. At the same time, Thailand (4.51\%), Egypt (3.61\%), Malaysia (3.5\%), Nigeria (3.48\%), South Africa (3.41\%), China (3.15\%) and India (3.07\%) experienced moderate growth. Average growth rates for GDP per capita indicate that China was the leader by far (8.91\%), followed by Thailand (4.35\%) and India (4.33\%). However, the growth of GDP per capita in Venezuela (0.20\%), South Africa (0.33\%), Argentina (0.63\%) and Algeria (0.68\%) were the lowest among the selected countries. The industrial growth rates show that Iran (1.85\%) and Thailand (1.34\%) have greater growth, while South Africa (1.62\%), Brazil (-1.31\%), Argentina (-0.78\%), the Philippines (-0.66\%), Pakistan ($0.21 \%)$ and China (-0.17\%) experienced negative growth.

The highest average growth rates of per capita oil consumption belong to China (4.71\%), Thailand (4.15\%) and India (3.72\%), while Nigeria (-0.86) and the Philippines $(-1.07 \%)$ had the lowest growth rates. Finally, the growth rates for trade openness suggest that the selected countries can be classified into four groups. The first one enjoyed rapid growth, maintaining more than 3\% average growth rates, includes

\footnotetext{
${ }^{4}$ Growth rates are calculated using original data (before converting into natural logarithms).
} 
Argentina (5.33\%), Turkey (4.57\%), India (4.39\%), Mexico (4.03\%), Thailand (3.48\%) and China (3.31\%). The second group observed modest growth rates ranging from 1\% to $3 \%$ namely Nigeria (2.86\%), Iran (2.36\%), Brazil (1.51\%), Malaysia (1.38\%), Venezuela (1.04\%), the Philippines (0.99 or 1\%) and Indonesia (0.92 or $1 \%)$. The third group had experienced very low but positive growth rates such as Colombia (0.79\%), Algeria (0.58\%) and South Africa (0.25\%). Lastly, the fourth group covers two economies, Pakistan (-0.12\%) and Egypt (-0.75\%), who experienced negative growth.

\section{[Insert Table 2 Here]}

\section{Unconditional correlations among the variables}

The unconditional correlations ${ }^{5}$ between the panel data variables are presented in Table 3. This table reflects that $\mathrm{CO}_{2}$ emissions have the highest correlation with oil and GDP per capita and the lowest correlation with trade openness. Financial development has the strongest relationship with trade openness and $\mathrm{CO}_{2}$ emissions and the weakest relationship with GDP per capita. Likewise, GDP per capita is significantly correlated with oil and $\mathrm{CO}_{2}$ emissions and least correlated with financial development. The highest correlation for oil consumption is with GDP per capita and $\mathrm{CO}_{2}$ emissions, while the lowest correlation is with FD. Finally, trade openness has a moderate correlation with all variables except GDP per capita. The most significant point that can be ascertained from Table 3 is that oil consumption is strongly correlated with GDP per capita and $\mathrm{CO}_{2}$ emissions, which suggests that the consumption of oil increases both GDP per capita and $\mathrm{CO}_{2}$ emissions, and vice versa. A similar link is also revealed in the case of real

\footnotetext{
${ }^{5}$ Unconditional correlations are calculated using data in natural logarithms.
} 
GDP per capita and $\mathrm{CO}_{2}$ emissions where these two variables have the highest correlations with oil consumption and between them. This therefore indicates that these three variables have a significant relationship in selected economies.

\section{[Insert Table 3 Here]}

Results of unit root tests

In this paper, we employ two panel unit root tests that examine both common as well as individual unit root processes. For example, the Breitung (2000) test examines the null hypothesis of common unit root process against the alternative hypothesis of no unit root. Similarly, the Im et al. (2003) test examines the null hypothesis of individual unit root processes across the cross sections against the alternative hypothesis of some crosssections do not have a unit root. The results of these two unit root tests are presented in Table 4. The results at levels for both the tests show that the null hypothesis of a unit root (common as well as individual) cannot be rejected at the $1 \%$ or $5 \%$ significance levels for all the given variables. However, at first difference, the null hypothesis of unit root can be rejected at the $1 \%$ significance level for all of the variables. Hence, our results confirm that all of the variables have a unit root process at levels and are stationary at their first order differences. This indicates that all of the variables are integrated of order I (1).

\section{[Insert Table 4 Here]}




\section{Empirical Results and Discussion}

The aim of this section is to empirically investigate the long-run equilibrium relationship between $\mathrm{CO}_{2} \mathrm{E}$, FD, GDPPC, IND, OILCON and TRDOPN using three robust panel cointegration techniques. Further, we explore the short-run and long-run dynamic causal relationship between these variables using the VECM approach. The empirical results of these models are presented and discussed below.

\section{Results of cointegration tests}

The results of two unit root tests confirm that $\mathrm{CO}_{2}$ emissions, financial development, economic growth, industrialization, oil consumption, and trade openness are nonstationary at their levels, and stationary at their first order differences. Therefore, these unit root tests results indicate that a long-run equilibrium relationship may exist between all of these variables. Hence, we apply cointegration models to explore the long-run cointegration relationship between the dependent variable $\left(\mathrm{CO}_{2} \mathrm{E}\right)$ and the independent variables (FD, GDPPC, IND, OILLCON and TRDOPN). As previously discussed, in this study, we employ three robust panel cointegration techniques: the Fisher-type test using the approach developed by Johansen (Maddala and Wu, 1999), the Kao (1999) test, and finally the Pedroni $(1999,2004)$ test. The empirical results of these cointegration techniques are presented below.

The results of the Johansen-Fisher panel cointegration test are reported in Table 5. This test requires using an appropriate lag length for the analysis. We therefore select the suitable lag length for this test based on the SIC and we also confirmed that the selected lag length residuals are random. The results of this test on both the trace and maximum 
eigen tests suggest that the null hypothesis of no cointegration is rejected at the $5 \%$ significance level. This therefore indicates that the variables of FD, GDPPC, IND, OILCON and TRDOPN are strongly cointegrated with $\mathrm{CO}_{2} \mathrm{E}$. Our results confirm that these variables share a long-run equilibrium relationship in the case of major oilconsuming emerging economies of the world.

\section{[Insert Table 5 Here]}

Likewise, we explore the long-run relationship between the same variables using the methodology developed by Kao (1999), the results of which are displayed in Table 6 . This test, based on the Engle-Granger approach, is similar to Pedroni (1999, 2004) cointegration test; however, it defines specific cross-section intercepts and homogenous coefficients on the first stage of regressors. This cointegration test also requires an appropriate lag length for the analysis, which we select based on the SIC. The results of this test reveal that the null hypothesis of no cointegration is rejected at the $1 \%$ significance level. These results suggest that there is a long-run equilibrium relationship between $\mathrm{CO}_{2} \mathrm{E}$, FD, GDPPC, IND, OILCON and TRDOPN.

\section{[Insert Table 6 Here]}

Finally, we apply the Pedroni (1999, 2004) panel cointegration test to investigate the long-run relationship between the given variables, and the empirical results are reported in Table 7. The Pedroni cointegration test is also based on the Engle-Granger approach. To perform the Pedroni cointegration test, first we have to identify the suitable lag length, which is chosen based on the SIC and it is also confirmed that the residuals of selected lag length are random. The results of Pedroni test show that out of the seven 
statistics, two statistics (within-dimension) reject the null hypothesis of no cointegration at the $10 \%$ and $5 \%$ level of significances, respectively. At the same time, two statistics (between-dimension) reject the null hypothesis of no cointegration at the $1 \%$ significance level. The results of Pedroni cointegration test on both within and between dimensions confirm that there is a long-run equilibrium relationship between $\mathrm{CO}_{2} \mathrm{E}, \mathrm{FD}$, GDPPC, IND, OILCON and TRDOPN in emerging economies. Overall, our three panel cointegration tests results indicate that there is substantial evidence of a long-run relationship between the studied variables.

\section{[Insert Table 7 Here]}

Results of dynamic short-run and long-run causal relationship

We aim to empirically investigate the dynamic short-run and long-run causal relationship between $\mathrm{CO}_{2} \mathrm{E}$, FD, GDPPC, IND, OILCON and TRDOPN. To achieve this, we follow the two-step approach developed by Engle-Granger (1987). This methodology is based on the VECM framework. The lag length for this model is selected based on the Akaike information criterion (AIC), which ensures that the residuals of the chosen lag length are random. For the purpose of interpretation and discussion of these results, we use $1 \%, 5 \%$ and $10 \%$ significance levels. Our primary variables of interest in this study are $\mathrm{CO}_{2}$ emissions, economic growth and oil consumption. The dynamic Granger causality tests results on short-run and long-run are presented in Table 8. The short-run Granger causality results display that there is an evidence of a feedback relationship between $\mathrm{CO}_{2}$ emissions-economic growth and $\mathrm{CO}_{2}$ emissions-oil consumption. Similarly, there is bidirectional causality between economic 
growth-oil consumption and economic growth-trade openness. We also found unidirectional causality that runs from industrialization to economic growth. Finally, oil consumption has a feedback relationship with $\mathrm{CO}_{2}$ emissions, economic growth and trade openness. Oil consumption is also driven by industrialization.

The short-run Granger causality results suggest that significant growth in economic expansion and oil consumption leads to higher $\mathrm{CO}_{2}$ emissions in emerging economies. This indicates that as the economies of those countries grow, their economic activities will significantly increase consumption of oil which will eventually lead to more and more $\mathrm{CO}_{2}$ emissions. Thus, $\mathrm{CO}_{2}$ emissions have a positive impact on economic growth, industrialization, oil consumption and trade openness. In the short-run, increase in $\mathrm{CO}_{2}$ emissions has several positive indications; however, it is going to be a major concern in the long-term. Therefore, policymakers and environmental scientists have to work out clearly on minimizing the $\mathrm{CO}_{2}$ emissions, particularly in emerging countries. The reason being is that in emerging countries both policymakers and government officials are more concerned about the economic problems such as, poverty and unemployment than the environmental problems.

The results on long-run (error correction term) causality shows that $\mathrm{CO}_{2}$ emissions, economic growth, financial development, oil consumption and trade openness have bidirectional causality. These long-run causality results suggest that the economic expansion of emerging economies is heavily dependent on the functioning and contributions of financial development, oil consumption, exports and imports of goods and services and $\mathrm{CO}_{2}$ emissions. Similarly, the consumption of oil is also largely dependent on financial development, economic growth and the role of international 
trade. Overall, our results on short-run and long-run causality suggest that there is a significant dynamic causal relationship between $\mathrm{CO}_{2}$ emissions, economic growth and oil consumption in emerging economies. The results of long-run causalities are consistent with those found by Al-mulali (2011) and Behmiri and Manso (2012b).

\section{[Insert Table 8 Here]}

\section{Conclusion}

A number of previous studies examine the nexus between energy consumptioneconomic growth, energy consumption-industrialization and energy consumptionfinancial development. However, a small amount of literature exists on the impact of economic growth, financial development, industrialization, trade openness and energy consumption on $\mathrm{CO}_{2}$ emissions. Additionally, the previous studies have failed to consider the impact of oil consumption on $\mathrm{CO}_{2}$ emissions by taking economic growth, financial development and industrialization and trade openness into account. Furthermore, the previous studies have not explored the linkage between these variables, particularly in the case of major oil-consuming emerging economies. Therefore, in this study we aim to examine the impact of economic growth, financial development, industrialization, oil consumption and trade openness on the $\mathrm{CO}_{2}$ emissions of a panel of 18 major oil-consuming emerging economies.

The empirical results of three panel cointegration models suggest that a significant longrun equilibrium relationship exists between economic growth, financial development, industrialization, oil consumption, trade openness and $\mathrm{CO}_{2}$ emissions. This evidence indicates that all of these variables share a common trend in the long-run. Furthermore, 
results from short-run Granger causality test display a dynamic feedback relationship between economic growth, oil consumption and $\mathrm{CO}_{2}$ emissions. Similarly, the results also show bidirectional causality between economic growth and trade openness and unidirectional causality from industrialization to economic growth. In addition, oil consumption also has bidirectional causality with trade openness and unidirectional causality from industrialization to oil consumption. Further, the results indicate that $\mathrm{CO}_{2}$ emissions, economic growth, financial development, oil consumption and trade openness have a bidirectional causal relationship in the long-run (error correction term).

The results on both the short-run and long-run causality indicate that significant growth in economic activities and oil consumption leads to larger $\mathrm{CO}_{2}$ emissions in emerging economies. These results suggest that as the economies of those countries grow, their economic activities will lead to increase oil consumption, which will ultimately release a significant amount of $\mathrm{CO}_{2}$ emissions into the atmosphere. Our evidence shows that $\mathrm{CO}_{2}$ emissions have a positive impact on economic growth, industrialization, oil consumption and trade openness in the short-run. This argument for the short-run suggests that an increase in $\mathrm{CO}_{2}$ emissions has a positive impact on the creation of wealth and opportunities. However, it may be a major concern in the long-term if a significant amount of attention is not paid to this issue. Therefore, we suggest that policymakers and environmental scientists of those emerging countries work towards minimizing $\mathrm{CO}_{2}$ emissions. It is understood that both policymakers and government officials in emerging economies are often more concerned about the economic problems that their countries are facing, such as poverty and unemployment, than the long-term effects of $\mathrm{CO}_{2}$ emissions. 
The major inferences of this study are as follows. A significant amount of $\mathrm{CO}_{2}$ emissions is caused by increased economic activities and oil consumption. This has important policy implications for energy and environmental policies. The economic policies designed for expanding economic activities will increase oil consumption and lead to higher $\mathrm{CO}_{2}$ emissions. If the predictions for future economic expansion are made without considering the supply and demand for oil, then the expected economic growth rates may not be met. Further, we argue that the consumption of oil has a severe impact on the environment, therefore policymakers and environmental scientists should develop policies to promote the use of renewable resources rather than non-renewable resources like oil. Furthermore, environmental policies that are designed for reducing oil consumption will adversely affect economic growth. Hence, better energy and environmental policies have to be designed in such a way that they will facilitate an increase in demand for energy consumption by increasing the share of renewable energy resources. As discussed above, our study offers significant contributions to the body of knowledge on the context of $\mathrm{CO}_{2}$ emissions, economic growth and oil consumption, particularly in the perspective of major oil-consuming emerging economies and has important policy implications to mitigate environmental degradation and ensure sustainable economic development. 


\section{Refferences}

Akinlo, A. E. (2008) Energy consumption and economic growth:evidence from 11 Sub-Sahara African countries, Energy Economics, 30, 2391-400.

Alam, M. J., Begum, I. A., Buysse, J., Rahman, S.and Van Huylenbroeck, G. (2011) Dynamic modeling of causal relationship between energy consumption, $\mathrm{CO}_{2}$ emissions and economic growth in India, Renewable and Sustainable Energy Reviews, 15, 3243-51.

Al-Mulali, U. (2011) Oil consumption, $\mathrm{CO}_{2}$ emission and economic growth in MENA countries, Energy, 36, 6165-71.

Apergis, N., Payne, James E., Menyah, K. and Wolde-Rufael, Y. (2010) On the causal dynamics between emissions, nuclear energy, renewable energy, and economic growth, Ecological Economics, 69, 2255-60.

Aqeel, A. and Butt, Mohammad S. (2001) The relationship between energy consumption and economic growth in Pakistan, Asia-Pacific Development Journal, 8, 101-10.

Behmiri, N. B and Manso, J. R. P. (2012a) Does Portuguese economy support crude oil conservation hypothesis?, Energy Policy, 45, 628-34.

Behmiri, N. B and Manso, J. R. P. (2012b) Crude oil conservation policy hypothesis in OECD (organisation for economic cooperation and development) countries: A multivariate panel Granger causality test, Energy, 43, 253-60.

Behmiri, N. B and Manso, J. R. P. (2013) How crude oil consumption impacts on economic growth of Sub-Saharan Africa?, Energy, 54, 74-83.

Bildirici, M. E. and Bakirtas, T. (2014) The relationship among oil, natural gas and coal consumption and economic growth in BRICTS (Brazil, Russian, India, China, Turkey and South Africa) countries, Energy, 65, 134-44.

Bildirici, M. E. and Kayıkçı, F. (2013) Effects of oil production on economic growth in Eurasian countries: Panel ARDL approach, Energy, 49, 156-61.

BP (2007) The BP Statistical Review of World Energy. British Petroleum, London, UK. Avialbale at http://www.bp.com/statistical.review.

Breitung, J. (2000) The local power of some unit root tests for panel data, in Baltagi, B. (ed.), Advances in Econometrics, 15, 161-178: Nonstationary Panels, Panel Cointegration, and Dynamic Panels, Amsterdam: JAI Press.

Chu, H.-P. and Chang, T. (2012) Nuclear energy consumption, oil consumption and economic growth in G-6 countries: Bootstrap panel causality test, Energy Policy, 48, 762-69.

Dickey, D. A. and Fuller, W. A. (1979) Distribution of the estimators for autoregressive time series with a unit root, Journal of the American statistical association, 74, 427-31.

EIA (2014). Analysis and Projections. U.S. Energy Information Administration, Washington, DC. U.S. Available at http://www.eia.gov/forecasts/steo/report.

Engle, R. F. and Granger, C.W.J. (1987) Co-integration and error correction: representation, estimation, and testing, Econometrica: journal of the Econometric Society, 251-76.

Fisher, I. (1932) Booms and depressions: some first principles, Adelphi Company, New York.

Ghani, G. M. (2012) Does trade liberalization effect energy consumption?, Energy Policy, 43, 28590.

Ghosh, S. (2010) Examining carbon emissions economic growth nexus for India: A multivariate cointegration approach. Energy Policy, 38, 3008-14.

Grossman, G. M. and Krueger, A. B. (1991) Environmental impacts of a North American free trade agreement: National Bureau of Economic Research.

Halicioglu, F. (2009) An econometric study of $\mathrm{CO}_{2}$ emissions, energy consumption, income and foreign trade in Turkey, Energy Policy, 37, 1156-64.

Halkos, G. E. and Tzeremes, N. G. (2011) Oil consumption and economic efficiency: A comparative analysis of advanced, developing and emerging economies, Ecological Economics, 70, 1354-62. 
Hamit-Haggar, M. (2012) Greenhouse gas emissions, energy consumption and economic growth: A panel cointegration analysis from Canadian industrial sector perspective, Energy Economics, 34, $358-64$.

He, K., Huo, H., Zhang, Q., He, D., An, F., Wang, M. and Walsh, M. P. (2005) Oil consumption and $\mathrm{CO}_{2}$ emissions in China's road transport: current status, future trends, and policy implications, Energy policy, 33, 1499-507.

Hossain, S. (2011) Panel estimation for $\mathrm{CO}_{2}$ emissions, energy consumption, economic growth, trade openness and urbanization of newly industrialized countries, Energy Policy, 39, 6991-99.

IEA (2013) IEA Statistics. International Energy Agency, Paris, France. Available at http://www.iea.org/publications/freepublications/publication/co2emissionsfromfuelcombustionh ighlights2013.pdf

Im, K.S., Pesaran, M. H. and Shin, Y. (2003) Testing for unit roots in heterogeneous panels, Journal of econometrics, 115, 53-74.

Jalil, A. and Feridun, M. (2011) The impact of growth, energy and financial development on the environment in China: A cointegration analysis, Energy Economics, 33, 284-91.

Jena, P. R, and Grote, U. (2008) Growth-trade-environment nexus in India, In: Proceedings of the German Development Economics Conference, Zurich.

Jensen, V. (1996). The pollution haven hypothesis and the industrial flight hypothesis: some perspectives on theory and empirics, Working Paper 5, Centre for Development and the Environment, University of Oslo.

Jones, D. W. (1991) How urbanization affects energy-use in developing countries, Energy Policy, 19, 621-30.

Kao, C. (1999) Spurious regression and residual-based tests for cointegration in panel data, Journal of econometrics, 90, 1-44.

Koch, N. (2014) Dynamic linkages among carbon, energy and financial markets: a smooth transition approach, Applied Economics, 46, 715-29.

Kumbaroğlu, G., Karali, N. and Arıkan, Y. (2008) $\mathrm{CO}_{2}$, GDP and RET: An aggregate economic equilibrium analysis for Turkey, Energy Policy, 36, 2694-708.

Lanoie, P., Laplante, B. and Roy, M. (1998) Can capital markets create incentives for pollution control?, Ecological Economics, 26, 31-41.

Lean, H. H, and Smyth, R. (2010) $\mathrm{CO}_{2}$ emissions, electricity consumption and output in ASEAN, Applied Energy, 87, 1858-64.

Lee, C-C. and Chang, C.-P. (2005) Structural breaks, energy consumption, and economic growth revisited: evidence from Taiwan, Energy Economics, 27, 857-72.

Loizides, J. and Vamvoukas, G. (2005) Government expenditure and economic growth: evidence from trivariate causality testing, Journal of Applied Economics, 8, 125-52.

Lucas, G, W. N. and Hettige, R. (1992) The inflexion point of manufacture industries: international trade and environment, World Bank discussion paper(148).

Lütkepohl, H. (1982) Non-causality due to omitted variables, Journal of Econometrics, 19, 367-78

Maddala, G. S. and Wu, S. (1999) A comparative study of unit root tests with panel data and a new simple test, Oxford Bulletin of Economics and statistics, 61, 631-52.

MacKinnon, J.G., Haug, A.A. and Michelis, L. (1999) Numerical distribution functions of likelihood ratio tests for cointegration, Journal of Applied Econometrics, 14, 563 - 57.

Mehrara, M. (2007) Energy consumption and economic growth: the case of oil exporting countries, Energy policy, 35, 2939-45.

Menyah, K. and Wolde-Rufael, Y. (2010) $\mathrm{CO}_{2}$ emissions, nuclear energy, renewable energy and economic growth in the US, Energy Policy, 38, 2911-15.

Nahman, A. and Antrobus, G. (2005) Trade and the environmental Kuznets curve: is Southern Africa a pollution haven?, South African journal of economics, 73, 803-14. 
Ozturk, I. and Acaravci, A. (2013) The long-run and causal analysis of energy, growth, openness and financial development on carbon emissions in Turkey, Energy Economics, 36, 262-67.

Pao, H-T. and Tsai, C.-M. (2010) $\mathrm{CO}_{2}$ emissions, energy consumption and economic growth in BRIC countries, Energy policy, 38, 7850-60.

Park, S.-Y, \& Yoo, S.-H. (2014) The dynamics of oil consumption and economic growth in Malaysia, Energy Policy, 66, 218-23.

Pedroni, P. (1999) Critical values for cointegration tests in heterogeneous panels with multiple regressors, Oxford Bulletin of Economics and statistics, 61, 653-70.

Pedroni, P. (2004) Panel cointegration: asymptotic and finite sample properties of pooled time series tests with an application to the PPP hypothesis, Econometric theory, 20, 597-25.

Poumanyvong, P. and Kaneko, S. (2010) Does urbanization lead to less energy use and lower $\mathrm{CO}_{2}$ emissions? A cross-country analysis, Ecological Economics, 70, 434-44.

Ren, S. Yuan, B., Ma, X. and Chen, X. (2014) International trade, FDI (foreign direct investment) and embodied $\mathrm{CO}_{2}$ emissions: A case study of Chinas industrial sectors, China Economic Review, 28, 123-34.

Sadorsky, P. (2010) The impact of financial development on energy consumption in emerging economies, Energy Policy, 38, 2528-35.

Sadorsky, P. (2011) Trade and energy consumption in the Middle East, Energy Economics, 33, 73949.

Sadorsky, P. (2012) Energy consumption, output and trade in South America, Energy Economics, 34, 476-88.

Sadorsky, P. (2013) Do urbanization and industrialization affect energy intensity in developing countries?, Energy Economics, 37, 52-59.

Sadorsky, P. (2014) The effect of urbanization and industrialization on energy use in emerging economies: Implications for sustainable development, American Journal of Economics and Sociology, 73, 392-409.

Shahbaz, M., Salah Uddin, G., Ur Rehman, I. and Imran, K. (2014) Industrialization, electricity consumption and $\mathrm{CO}_{2}$ emissions in Bangladesh, Renewable and Sustainable Energy Reviews, 31, 575-86.

Soytas, U. and Sari, R. (2009) Energy consumption, economic growth, and carbon emissions: challenges faced by an EU candidate member, Ecological economics, 68, 1667-75.

Stern, D.I. (1993) Energy and economic growth in the USA: a multivariate approach, Energy Economics, 15, 137-50.

Tamazian, A., Chousa, Juan P. and Vadlamannati, K. C. (2009) Does higher economic and financial development lead to environmental degradation: evidence from BRIC countries, Energy Policy, 37, 246-53.

Tamazian, A. and Bhaskara R. B. (2010) Do economic, financial and institutional developments matter for environmental degradation? Evidence from transitional economies, Energy Economics, 32, 137-45.

Tsani, S. Z. (2010) Energy consumption and economic growth: a causality analysis for Greece, Energy Economics, 32, 582-90.

Wolde-Rufael, Y. (2004) Disaggregated industrial energy consumption and GDP: the case of Shanghai, 1952-1999, Energy economics, 26, 69-75.

Wolde-Rufael, Y. and Menyah, K. (2010) Nuclear energy consumption and economic growth in nine developed countries, Energy Economics, 32,550-56.

Wyckoff, A.W. and Roop, J.M. (1994), The embodiment of carbon in imports of manufactured products: Implications for international agreements on greenhouse gas emissions, Energy policy, 22, 187-94.

Yoo, S.-H. (2006) Oil consumption and economic growth: evidence from Korea, Energy Sources, 1,235-43. 
York, R., Rosa, E.A. and Dietz, T. (2003) STIRPAT, IPAT and ImPACT: analytic tools for unpacking the driving forces of environmental impacts, Ecological economics, 46, 351-65.

Yang, H.-Y. (2000) A note on the causal relationship between energy and GDP in Taiwan, Energy Economics, 22, 309-17.

Yuan, J., Zhao, C., Yu, S., and Hu, Z. (2007) Electricity consumption and economic growth in China: cointegration and co-feature analysis, Energy Economics, 29, 1179-91.

Yuan, J.-H, Kang, J.-G, Zhao, C.-H and Hu, Z.-G. (2008) Energy consumption and economic growth: evidence from China at both aggregated and disaggregated levels, Energy Economics, 30, 3077-94.

Zamani, M. (2007) Energy consumption and economic activities in Iran, Energy Economics, 29, $1135-40$.

Zhang, X.-P. and Cheng, X.-M. (2009) Energy consumption, carbon emissions, and economic growth in China, Ecological Economics, 68, 2706-12.

Zhang, Y.-J. (2011). The impact of financial development on carbon emissions: An empirical analysis in China, Energy Policy, 39, 2197-203.

Zou, G. and Chau, K.W. (2006) Short-and long-run effects between oil consumption and economic growth in China, Energy Policy, 34, 3644-655. 
Table 1: Summary of the relevant literature

\begin{tabular}{|c|c|c|c|c|}
\hline Authors & Country & Period & Variables & Conclusion \\
\hline $\begin{array}{l}\text { Aqeel and Butt } \\
(2001)\end{array}$ & Pakistan & $1956-1996$ & $\begin{array}{l}\text { GDP growth, petroleum, gas and electricity } \\
\text { consumption }\end{array}$ & $\begin{array}{l}\mathrm{GDP} \rightarrow \text { Oil } \\
\mathrm{GDP} \neq \text { Gas } \\
\mathrm{GDP} \rightarrow \mathrm{EC}\end{array}$ \\
\hline Al-mulali (2011) & MENA countries & 1980-2009 & Oil consumption, $\mathrm{CO}_{2}$ emissions and GDP & $\begin{array}{l}\mathrm{GDP} \longleftrightarrow \mathrm{Oil} \\
\mathrm{Oil} \leftrightarrow \mathrm{CO}_{2}\end{array}$ \\
\hline $\begin{array}{l}\text { Behmiri and Manso } \\
\text { (2012b) }\end{array}$ & $\begin{array}{l}27 \text { OECD } \\
\text { countries }\end{array}$ & 1976-2009 & $\begin{array}{l}\text { Oil consumption, oil price, exchange rate and real } \\
\text { GDP per capita }\end{array}$ & GDP $\leftrightarrow$ Oil \\
\hline $\begin{array}{l}\text { Behmiri and Manso } \\
\text { (2013) }\end{array}$ & $\begin{array}{l}\text { Sub-Saharan } \\
\text { Africa }\end{array}$ & 1985-2011 & Oil consumption, oil price and GDP per capita & $\begin{array}{l}\text { GDP } \leftrightarrow \text { Oil (oil importing } \\
\text { countries) } \\
\text { Oil } \rightarrow \text { GDP (oil exporting } \\
\text { countries) }\end{array}$ \\
\hline $\begin{array}{l}\text { Bildirici and Kaykci } \\
\text { (2013) }\end{array}$ & $\begin{array}{l}\text { Eurasian } \\
\text { countries }\end{array}$ & 1993-2010 & Oil production and GDP per capita & Oil $\leftrightarrow$ GDP \\
\hline Fatai et al. (2004) & New Zealand & 1960-1999 & Oil consumption and real GDP & Oil $\neq$ GDP \\
\hline $\begin{array}{l}\text { Halkos and } \\
\text { Tzeremes (2011) }\end{array}$ & 42 countries & 1986-2006 & Oil consumption and economic efficiency & Oil $\longrightarrow$ Economic efficiency \\
\hline $\begin{array}{l}\text { Lee and Chang } \\
(2005)\end{array}$ & Taiwan & 1954-2003 & $\begin{array}{l}\text { Oil, gas, electricity and coal consumption and real } \\
\text { GDP }\end{array}$ & $\begin{array}{l}\text { Oil, gas, electricity } \rightarrow \text { GDP } \\
\text { Coal } \leftrightarrow \text { GDP }\end{array}$ \\
\hline Park and Yoo (2014) & Malaysia & 1965-2011 & Oil consumption and real GDP & Oil $\longleftrightarrow$ GDP \\
\hline Yang (2000) & Taiwan & 1954-1997 & Oil consumption and real GDP & GDP $\rightarrow$ Oil \\
\hline Yaun et al. (2008) & China & 1963-2005 & $\begin{array}{l}\text { Oil consumption, employment, net value of fixed } \\
\text { assets of all industries and real GDP }\end{array}$ & $\begin{array}{l}\text { Oil } \leftrightarrow \text { GDP } \\
\text { Electricity } \rightarrow \text { GDP } \\
\text { GDP } \rightarrow \text { Coal }\end{array}$ \\
\hline $\begin{array}{l}\text { Zou and Chau } \\
\text { (2006) }\end{array}$ & China & $1953-2002$ & Oil consumption and real GDP & $\mathrm{Oil} \leftrightarrow$ GDP \\
\hline Zamani (2007) & Iran & 1967-2003 & $\begin{array}{l}\text { Aggregated and disaggregated energy consumption, } \\
\text { Industrial and agricultural value added and real GDP }\end{array}$ & $\begin{array}{l}\text { GDP } \longleftrightarrow \text { Petroleum, Gas } \\
\text { GDP } \longrightarrow \text { Aggregate Energy }\end{array}$ \\
\hline
\end{tabular}

Note: $\rightarrow$ and $\longleftrightarrow$, $\neq$ indicate unidirectional bidirectional and no causality, respectively. 
Table 2: Average annual growth rates 1980-2012 (percentage)

\begin{tabular}{lllllll}
\hline Country & $\mathrm{CO}_{2} \mathrm{E}$ & $\mathrm{FD}$ & GDPPC & IND & OILCON & TRDOPN \\
\hline Algeria & 0.698 & 0.500 & 0.683 & -0.293 & 1.071 & 0.576 \\
Argentina & 0.598 & 2.096 & 0.630 & -0.775 & 0.017 & 5.334 \\
Brazil & 1.158 & 6.011 & 1.011 & -1.313 & 1.390 & 1.511 \\
China & 4.663 & 3.151 & 8.908 & -0.168 & 4.705 & 3.307 \\
Colombia & 0.101 & 2.362 & 1.753 & 0.535 & 0.107 & 0.796 \\
Egypt & 3.245 & 3.606 & 2.802 & 0.329 & 1.603 & -0.750 \\
India & 3.875 & 3.070 & 4.328 & 0.272 & 3.722 & 4.385 \\
Indonesia & 3.530 & 6.045 & 3.690 & 0.438 & 2.698 & 0.924 \\
Iran & 3.108 & -1.707 & 1.446 & 1.854 & 1.310 & 2.357 \\
Malaysia & 4.662 & 3.502 & 3.482 & 0.046 & 1.989 & 1.379 \\
Mexico & 0.199 & 2.638 & 0.816 & 0.328 & 0.027 & 4.038 \\
Nigeria & -0.151 & 3.481 & 0.986 & 0.342 & -0.860 & 2.856 \\
Pakistan & 2.729 & -0.685 & 2.124 & -0.213 & 2.112 & -0.122 \\
Philippines & 0.567 & 1.256 & 1.015 & -0.657 & -1.068 & 0.987 \\
South Africa & 0.574 & 3.407 & 0.334 & -1.624 & 0.149 & 0.249 \\
Thailand & 5.536 & 4.508 & 4.354 & 1.344 & 4.152 & 3.478 \\
Turkey & 2.878 & 5.373 & 2.719 & 0.550 & 1.021 & 4.570 \\
Venezuela & 0.764 & -0.210 & 0.196 & 0.868 & 0.186 & 1.038 \\
\hline
\end{tabular}

Note: Growth rates are calculated from original data.

Table 3: Correlations for the panel data set

\begin{tabular}{lllllll}
\hline Variable & $\mathrm{CO}_{2} \mathrm{E}$ & $\mathrm{FD}$ & GDPPC & IND & OILCON & TRDOPN \\
\hline $\mathrm{CO}_{2} \mathrm{E}$ & 1 & 0.309 & 0.780 & 0.392 & 0.821 & 0.222 \\
$\mathrm{FD}$ & & 1 & 0.113 & 0.142 & 0.121 & 0.323 \\
GDPPC & & & 1 & 0.251 & 0.870 & 0.138 \\
Industry & & & & 1 & 0.320 & 0.421 \\
Petroleum & & & & & 1 & 0.239 \\
Trade & & & & & & 1 \\
\hline
\end{tabular}

Note: Variables were in natural logarithms. 
Table 4: Panel unit root tests

\begin{tabular}{|c|c|c|c|c|c|c|c|c|}
\hline \multirow[b]{4}{*}{ Variable } & \multirow{2}{*}{\multicolumn{4}{|c|}{$\begin{array}{l}\text { Breitung (2000) t-stat } \\
\text { Null: Common unit root process }\end{array}$}} & \multirow{2}{*}{\multicolumn{4}{|c|}{$\begin{array}{l}\text { Im, Pesaran and Shin (2003) W-stat } \\
\text { Null: Individual unit root process }\end{array}$}} \\
\hline & & & & & & & & \\
\hline & \multicolumn{2}{|l|}{ Level } & \multicolumn{2}{|c|}{ First Difference } & \multicolumn{2}{|l|}{ Level } & \multicolumn{2}{|c|}{ First Difference } \\
\hline & Statistic & Prob. $^{\mathrm{a}}$ & Statistic & Prob. $^{a}$ & Statistic & Prob. $^{a}$ & Statistic & Prob. $^{a}$ \\
\hline $\mathrm{CO}_{2} \mathrm{E}$ & -0.203 & 0.420 & $-9.948 * * *$ & 0.000 & 0.007 & 0.503 & $-18.566^{* * *}$ & 0.000 \\
\hline FD & 0.168 & 0.567 & $-9.789 * * *$ & 0.000 & -0.975 & 0.165 & $-13.512 * * *$ & 0.000 \\
\hline GDPPC & 3.315 & 1.000 & $-7.172 * * *$ & 0.000 & 6.036 & 1.000 & $-9.544 * * *$ & 0.000 \\
\hline Industry & -0.689 & 0.245 & $-8.667 * * *$ & 0.000 & -1.239 & 0.108 & $-17.300 * * *$ & 0.000 \\
\hline Petroleum & -0.662 & 0.254 & $-7.423 * * *$ & 0.000 & 0.231 & 0.591 & $-16.535 * * *$ & 0.000 \\
\hline Trade & -1.528 & 0.063 & $-10.709 * * *$ & 0.000 & -0.360 & 0.360 & $-19.622 * * *$ & 0.000 \\
\hline
\end{tabular}

Note: where ‘***' indicates rejection of null hypothesis of unit root at $1 \%$ significance level.

${ }^{a}$ Probability values for both the unit root tests are computed assuming asymptotic normality.

Table 5: Fisher-Johansen panel cointegration test results

\begin{tabular}{lllll}
\hline Ho & Fisher Stat.* & \multicolumn{3}{l}{ Fisher Stat.* } \\
\cline { 2 - 5 } & (from trace test) & Prob. & (from max-eigen test) & Prob. \\
\hline None & $335.500^{* * *}$ & 0.000 & $221.900^{* * *}$ & 0.000 \\
At most 1 & $153.200^{* * *}$ & 0.000 & $99.050^{* * *}$ & 0.000 \\
At most 2 & $76.440^{* * *}$ & 0.000 & $53.680^{* *}$ & 0.029 \\
At most 3 & 43.400 & 0.185 & 34.660 & 0.532 \\
At most 4 & 30.200 & 0.741 & 30.380 & 0.733 \\
At most 5 & 32.480 & 0.637 & 32.480 & 0.637 \\
\hline
\end{tabular}

Variables: $\mathrm{CO}_{2} \mathrm{E}$, FD, GDPPC, IND, OILCON \& TRDOPN;

Trend assumption: Linear deterministic trend;

Lag selection: Based on SIC;

$* * * \& * *$ denote rejection of the null hypothesis of no cointegration at the $1 \%$ and $5 \%$ significance levels, respectively.

Table 6: Kao residual panel cointegration test results

\begin{tabular}{lll}
\hline ADF & t-Statistic & Prob. \\
\cline { 2 - 3 } & $-3.870^{* * *}$ & 0.000 \\
\hline Residual variance & 0.005 & \\
HAC variance & 0.004 & \\
\hline
\end{tabular}

Variables: $\mathrm{CO}_{2} \mathrm{E}, \mathrm{FD}, \mathrm{GDPPC}$, IND, OILCON \& TRDOPN;

Trend assumption: No deterministic trend;

Lag selection: Automatic based on SIC with a max lag of 8;

Newey-West automatic bandwidth selection with Bartlett kernel;

*** denotes rejection of the null hypothesis of no cointegration at the $1 \%$ significance level. 
Table 7: Pedroni panel cointegration test results

\begin{tabular}{lccll}
\hline \multicolumn{5}{l}{ Alternative hypothesis: common AR coefs. (within-dimension) } \\
\hline & Statistic & Prob. & Weighted Statistic & Prob. \\
\hline Panel v-Statistic & -1.580 & 0.943 & -1.318 & 0.906 \\
Panel rho-Statistic & 1.575 & 0.942 & 0.641 & 0.739 \\
Panel PP-Statistic & $-1.633^{*}$ & 0.051 & $-4.183^{* * *}$ & 0.000 \\
Panel ADF-Statistic & $-1.894^{* *}$ & 0.029 & $-5.408^{* * *}$ & 0.000 \\
Alternative hypothesis: individual AR coefs. (between-dimension) & \\
\hline & Statistic & & Prob. \\
\hline Group rho-Statistic & 1.956 & & 0.975 & \\
Group PP-Statistic & $-4.560^{* * *}$ & & 0.000 & \\
Group ADF-Statistic & $-4.986^{* * *}$ & & 0.000 &
\end{tabular}

Variables: $\mathrm{CO}_{2} \mathrm{E}, \mathrm{FD}, \mathrm{GDPPC}$, IND, OILCON \& TRDOPN;

Trend assumption: No deterministic trend;

Lag selection: Automatic based on SIC with a max lag of 6;

Newey-West automatic bandwidth selection with Bartlett kernel;

$* * *, * * \& *$ denote rejection of null hypothesis of no cointegration at the $1 \%, 5 \%$ and $10 \%$ significance levels, respectively

Table 8: Granger causality test results

\begin{tabular}{|c|c|c|c|c|c|c|c|}
\hline & & $\Delta \mathrm{CO}_{2} \mathrm{E}$ & $\Delta \mathrm{FD}$ & $\triangle \mathrm{GDPPC}$ & $\Delta$ IND & $\triangle \mathrm{OILCON}$ & $\triangle \mathrm{TRDOPN}$ \\
\hline \multicolumn{8}{|c|}{ Short-run Granger causality } \\
\hline \multirow{2}{*}{$\Delta \mathrm{CO}_{2} \mathrm{E}$} & F-statistic & & 1.831 & $2.577 *$ & $5.306 * * *$ & $3.612^{* *}$ & $7.990 * * *$ \\
\hline & Prob. & & 0.141 & 0.053 & 0.001 & 0.013 & 0.000 \\
\hline \multirow[t]{2}{*}{$\Delta \mathrm{FD}$} & F-statistic & 0.885 & & 0.564 & $2.635^{* *}$ & 0.227 & 0.755 \\
\hline & Prob. & 0.449 & & 0.639 & 0.049 & 0.878 & 0.520 \\
\hline \multirow[t]{2}{*}{$\triangle \mathrm{GDPPC}$} & F-statistic & $2.447 *$ & $7.543 * * *$ & & 1.880 & $2.674^{* *}$ & $3.953 * * *$ \\
\hline & Prob. & 0.063 & 0.000 & & 0.132 & 0.047 & 0.008 \\
\hline \multirow[t]{2}{*}{$\Delta \mathrm{IND}$} & F-statistic & $3.502 * *$ & 0.105 & $2.718 * *$ & & $2.129 *$ & 0.627 \\
\hline & Prob. & 0.031 & 0.957 & 0.044 & & 0.096 & 0.598 \\
\hline \multirow[t]{2}{*}{$\triangle \mathrm{OILCON}$} & F-statistic & $2.102 *$ & 0.788 & $2.468 *$ & 1.898 & & $2.673^{* *}$ \\
\hline & Prob. & 0.099 & 0.501 & 0.061 & 0.129 & & 0.047 \\
\hline \multirow[t]{2}{*}{$\Delta$ TRDOPN } & F-statistic & 2.047 & 1.446 & $9.465^{* * *}$ & $6.640 * * *$ & $2.114^{*}$ & \\
\hline & Prob. & 0.106 & 0.229 & 0.000 & 0.000 & 0.098 & \\
\hline \multicolumn{8}{|c|}{ Long-run Granger causality } \\
\hline \multirow[t]{2}{*}{$\operatorname{Ect}(-1)$} & t-Statistic & $2.999 * * *$ & $-3.522 * * *$ & $3.436 * * *$ & -0.320 & $2.890^{* * *}$ & $1.995^{* *}$ \\
\hline & Prob. & 0.003 & 0.001 & 0.001 & 0.749 & 0.004 & 0.047 \\
\hline
\end{tabular}

Note: $\operatorname{Ect}(-1)$ represents the error correction term with one lagged period;

$\Delta$ represents the first difference;

The optimal lag length is selected based on the AIC;

$* * *, * * \& *$ denote rejection of null hypothesis of no Granger causality at the $1 \%, 5 \%$ and $10 \%$ significance levels, respectively. 